\title{
THE USE OF FERROUS GLUCONATE IN THE TREATMENT OF HYPOCHROMIC ANEMIA
}

\author{
By PAUL REZNIKOFF AND WALTHER F. GOEBEL \\ (From the New York Hospital and the Department of Medicine, Cornell University Medical \\ College, and the Hospital of the Rockefeller Institute for Medical Research, \\ New York City)
}

(Received for publication January 23, 1937)

Although hypochromic anemia due to iron deficiency is universally treated with iron medication, there is not as much unanimity with respect to the particular type of iron compound to be used. The following postulates, however, are accepted: The dosage must be adequate to insure a reasonably rapid increase of hemoglobin, the iron compound, in the dosage given, 'must be tolerated by the patient without undue distress, and the cost of medication must be within the financial means of the patient.

Many individuals receiving iron complain of such symptoms as nausea, epigastric discomfort, diarrhea or constipation. Some physicians hesitate to subject their patients to possible upset in cases of gastric or duodenal ulcer, colitis, and diarrhea or constipation. It was thought desirable, therefore, to prepare an iron compound which might have minimum irritating effects. One of the characteristics of ferric compounds is their ability to precipitate proteins. Most ferrous compounds are oxidized readily to the ferric state. This precipitating effect on proteins might explain the irritating action of iron compounds on the gastro-intestinal tract of some patients. Ferrous gluconate, prepared anaerobically, was found to have no precipitating action on proteins even when converted into the ferric state. It was decided, therefore, to treat patients with this compound to determine not only its efficacy but also its toxicity compared to medications now in common use. As a further test of its lack of toxic effects, solutions of ferrous gluconate were administered intramuscularly in quantities containing as much as $50 \mathrm{mgm}$. of iron, with no systemic disturbances and rarely with local discomfort. The method of preparing this substance and its use in treating hypochromic anemia in rats have been described previously (1).

Recently we have been able to simplify the method based upon a report of Neiger and Neuschul (2). These investigators, studying the photochemical reactions of ferrous gluconate, prepared dilute solutions of this salt by boiling aqueous gluconic acid with iron filings. Although these workers do not describe the isolation of the crystalline salt, it occurred to us that crystalline ferrous gluconate might be prepared in quantity and in a high state of purity by employing this simple reaction. Consequently 100 grams of crystalline calcium gluconate 1 were dissolved in $700 \mathrm{cc}$. of boiling water. A solution of 29.3 grams of oxalic acid dissolved in $150 \mathrm{cc}$. of warm water was added. The precipitated 'calcium oxalate was separated by filtration, and the clear filtrate containing gluconic acid was concentrated to $350 \mathrm{cc}$. in vacuo. The solution of gluconic acid was placed in a one liter, three necked, round bottomed flask bearing a mercury sealed stirrer. One outlet of the flask was fitted with a small water trap to permit the escape of evolved hydrogen gas whereas the third outlet was closed with a rubber stopper. The flask was now heated in a water bath, and the contents rapidly stirred. Twenty-six grams (2 equivalents) of pure powdered iron (Merck's "Iron by Hydrogen") were added. A rapid evolution of hydrogen took place. At the end of two hours the solution in the flask was neutral to litmus paper. The hot solution of ferrous gluconate, colored a pale green, was carefully filtered through a sintered 'glass funnel of fine porosity. The filtration was conducted in such a manner that at no time did the solution of ferrous gluconate come in contact with atmospheric oxygen. This was accomplished by conducting the solution from the reaction flask by suction into an enclosed filtering system in which all air had been displaced by carbon dioxide.

The solution was allowed to cool in an atmosphere of carbon dioxide and after crystallization of ferrous gluconate was complete, the product was filtered rapidly in a Buchner funnel, washed with a small amount of 50 per cent alcohol, and finally with pure acetone. The substance was 'placed in a vacuum desiccator to remove all traces of acetone. Eighty-eight grams of ferrous gluconate were recovered.

The product thus obtained is a fluffy white powder with a very slight greenish tint. The substance crystallizes with one molecule of water and contains no detectable ferric iron. The fer-

1 We have been able to simplify the preparation of ferrous gluconate still further recently by making it from technical gluconic acid. 
PAUL REZNIKOFF AND WALTHER F. GOEBEL

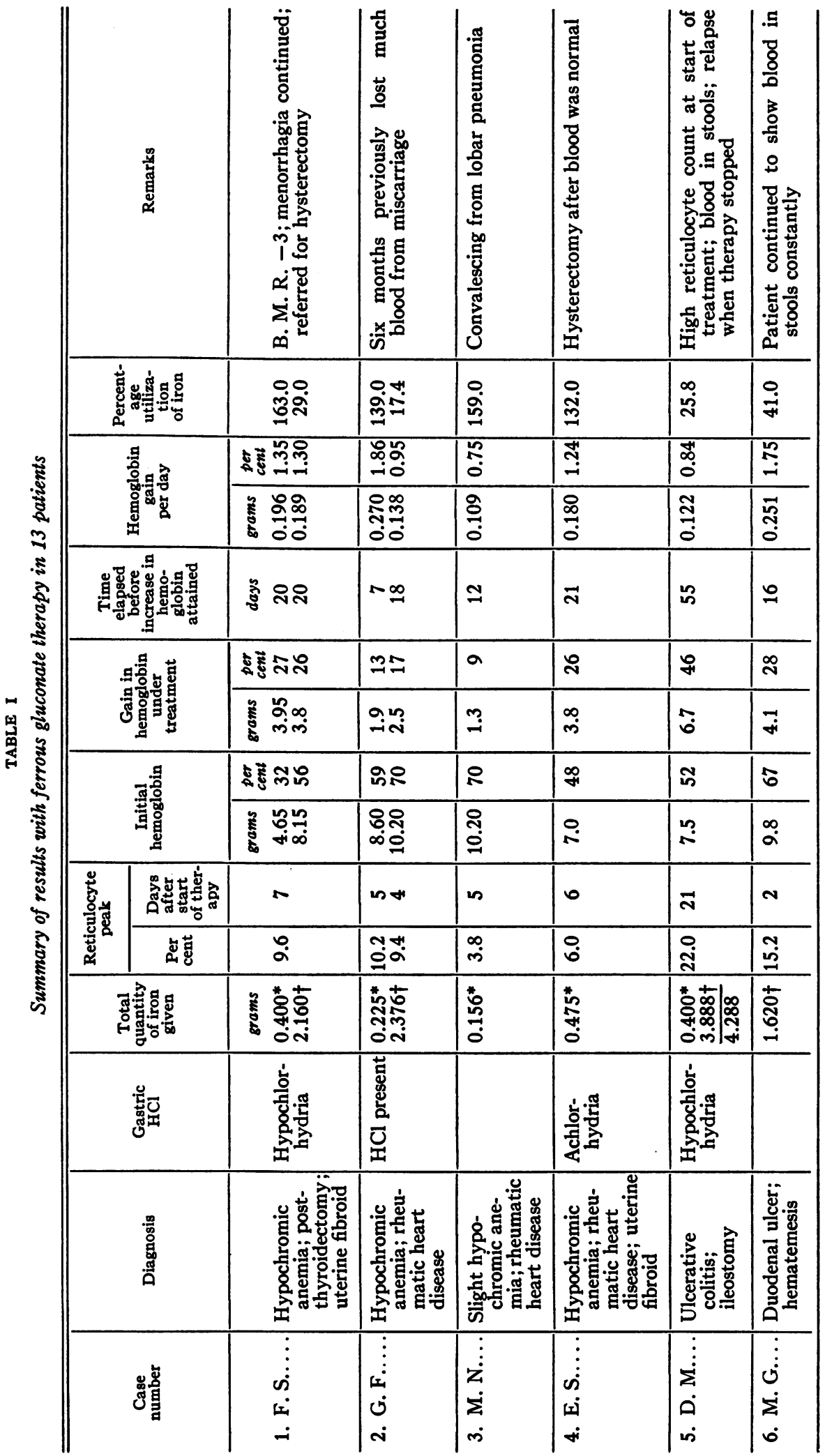


FERROUS GLUCONATE IN HYPOCHROMIC ANEMIA

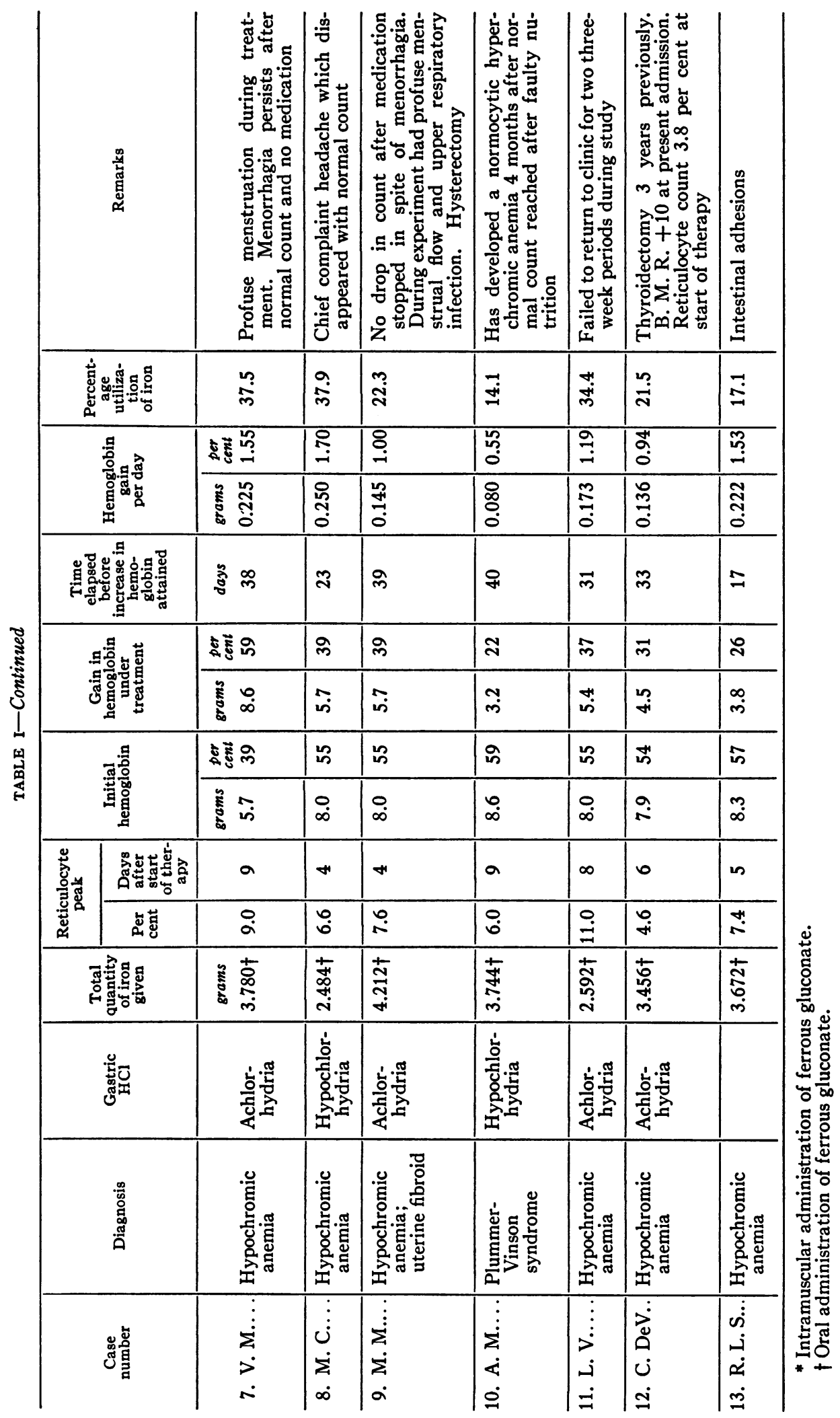


rous gluconate prepared in this manner is in all respects identical with that previously described. The above method, however, is considerably simpler than that originally described by us for the preparation of crystalline ferrous gluconate (1), and has the additional advantage of being more economical and more easily carried out.

Thirteen female patients ranging in age from 24 to 49 years and averaging 40 , and suffering from hypochromic anemia were treated with ferrous gluconate, two by intramuscular injection, eight by oral administration and three by both methods (Table I). In addition, two patients who had demonstrated marked intolerance to other iron compounds were given ferrous gluconate. In most instances, daily reticulocyte, red blood cell and hemoglobin determinations were made until normal values were obtained, and subsequently the blood was studied as frequently as seemed indicated. In this study 14.5 grams of hemoglobin per $100 \mathrm{cc}$. was equivalent to 100 per cent.

The diagnosis in four of the patients was "idiopathic" hypochromic anemia without complicating factors. In the others, the following conditions were found, in some cases more than one being present: intestinal adhesions, 1 ; post-thyroidectomy, 2 ; uterine fibroids, 3 ; previous miscarriages, 1 ; rheumatic heart disease, 3 ; ulcerative colitis and ileostomy, 1 ; duodenal ulcer, 1.

The initial hemoglobin was less than 7.25 grams per $100 \mathrm{cc}$., or 50 per cent, in 3 of the patients. In the remaining, the hemoglobin before medication was greater than 7.25 grams. This observation is important since Heath (3) states that a 1 per cent rise in hemoglobin per day is the low limit of a satisfactory response to treatment when the initial hemoglobin is below 50 per cent.

The volume index of one patient who had been bleeding from a duodenal ulcer was 0.97. Another had a volume index of 0.8 ; in two the determination was not made; and in the other nine, the values varied from 0.58 to 0.76 .

Gastric analysis was not performed in 3 cases. Of the rest, 1 had normal hydrochloric acid content after alcohol and histamine; 4 had hypochlorhydria; and 5, achlorhydria.

The anemia in all of these patients responded well to therapy. In only two did the hemoglobin level fail to reach 11.6 grams or 80 per cent and in these the toxicity of ferrous gluconate when given intramuscularly was tested and no attempt was made to complete the treatment with this iron salt. Six of the 13 patients attained hemoglobin values ranging from 13.1 grams (90 per cent) to 14.2 grams (98 per cent); and 5 , values ranging from 11.7 grams (81 per cent) to 12.6 ( 87 per cent).

Of the 13 patients, one had an initial erythrocyte count between $2,000,000$ and $2,500,000$; one, between 2,500,000 and 3,000,000; four, between $3,000,000$ and $3,500,000$; one, between $3,500,000$ and $4,000,000$; two, between $4,000,000$ and 4,500,000 ; and four, between 4,500,000 and 5,000,000. After treatment, three patients had erythrocyte counts between $4,000,000$ and $4,500,000$; five, between 4,500,000 and 5,000,000; and five, above $5,000,000$. Since this response of the red blood cells to treatment showed no abnormalities, this phase of the subject will not be considered further in this report.

Symptomatically, 7 patients were apparently cured with the attainment of a normal blood count. In 4, profuse menstrual bleeding persisted even after a normal blood count was reached. In 2 of these cases hysterectomy was performed (Cases 4 and 9); in the other two Cases 1 and 7), the blood count has been normal for five months in spite of the fact that they have continued to menstruate profusely and have received no medication. One patient (Case 5) who had an ileostomy for ulcerative colitis, became anemic again two months after the administration of ferrous gluconate was stopped although she received large doses of ferrous sulphate and intramuscular liver extract. Another patient (Case 10) returned three months after the cessation of ferrous gluconate therapy with evidences of hyperchromic anemia and a history of severe malnutrition. She is responding well to liver therapy.

The effect of ferrous gluconate therapy is summarized in Table I. An analysis of these results, without a critical consideration of each case, shows that with respect to the reticulocyte count, gain in hemoglobin per day, and percentage utilization of iron, the ferrous gluconate was strikingly effective in the 13 patients treated. Since in this study small oral doses of iron (108 $\mathrm{mgm}$. daily) were 


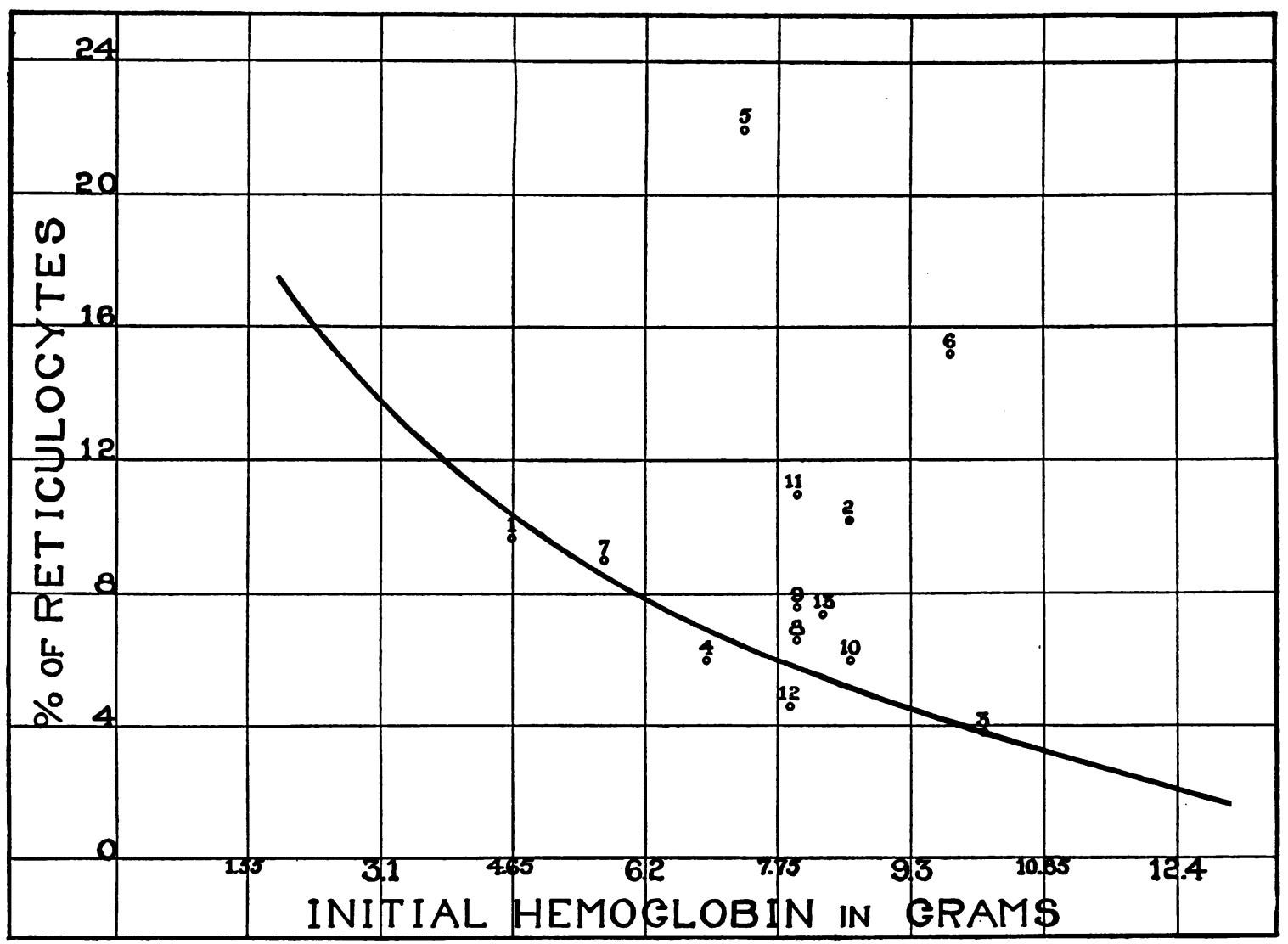

Fig. 1. Reticulocyte Peaks Attained by Patients Plotted on Heath's (3) Curve of Adequate Response

usually administered to determine the response to minimum dosage, the time elapsing before a normal blood count was obtained was not remarkable. However, when for purposes of expediency larger oral doses (216 mgm. daily) were given to $\mathrm{Pa}$ tients 2 and 13, normal blood counts were attained within three weeks. Patients 1, 6 and 8 showed a normal count with only $108 \mathrm{mgm}$. of iron daily in 20,16 and 23 days respectively. Case 6 , however, represents a posthemorrhagic patient, and the marked response may not be due chiefly to the therapy.

Figure 1 shows the reticulocyte peaks attained by the patients in this study. These are represented by a dot for each case when compared to Heath's curve (3) for adequate reticulocyte response. Patient 5 suffering from ulcerative colitis attained 22 per cent reticulocytes, but her initial count was 10 per cent. Patient 6 who suffered from hematemesis reached a peak of $\mathbf{1 5 . 2}$ per cent from an initial count of 12.6 per cent.
Obviously, these results cannot be considered to be entirely due to the treatment. Patient 12 attained a reticulocyte peak of only 4.6 per cent with an initial hemoglobin of 7.9 grams. But preliminary counts were as high as 2.4 per cent, and she had a red blood cell count of 4,800,000 before therapy was started which would tend to lower the peak.

The average daily increase of hemoglobin in the patients receiving ferrous gluconate intramuscularly, exclusive of Patient 5 in whom the results of intramuscular and oral administration overlapped, was 0.189 gram of 1.30 per cent. If Patient 3 is excluded because of her high initial count of 10.2 grams, the results with the remaining three patients, two of whom had initial hemoglobin values of less than 7.25 grams, give an average daily increase of hemoglobin for intramuscular therapy of 0.215 gram or 1.48 per cent. The average daily gain for all patients given ferrous gluconate orally was 0.181 gram or 1.25 per 
cent. It is obviously unfair to include Patient 6 in this 'series as the rapid rise in her hemoglobin following the acute hemorrhage is certainly not due to medication entirely. Patient 2 whose initial hemoglobin before oral therapy was started was 10.2 grams and Patient 10 who subsequently demonstrated a maturative deficiency probably should not be considered in this calculation. If the last two patients are included, the average daily gain of hemoglobin for the group is 0.173 gram or 1.19 per cent; if these two cases are excluded, the average daily gain of hemoglobin is 0.191 gram or 1.32 per cent. Patient 7 , the only one in the series whose initial hemoglobin was less than 7.25 grams before oral therapy was started, had a daily hemoglobin gain of 0.225 gram or 1.55 per cent. ${ }^{2}$

The percentage utilization of iron was calculated by multiplying the total 'gain in grams of hemoglobin per cubic centimeter for each patient by 5000 , the approximate adult blood volume, and by 0.0033 , the approximate percentage of iron in hemoglobin, and the result obtained was divided by the total amount of iron given the patient. The percentage utilization in the 4 patients who received intramuscular ferrous gluconate calculated in this manner was well over 100 per cent, actually averaging 148 per cent. This is in keeping with the findings of Heath, Strauss and Castle (4) and of Whipple and Robscheit-Robbins (5). Whether this is due to the erroneous assumption of blood volume as the former authors suggest or to a salt effect on iron stored in the body as the latter workers state cannot be determined by our experiments. The percentage utilization of iron in the patients receiving ferrous gluconate by mouth averaged 27.2. If the three patients excluded from the final calculations of the daily hemoglobin increase are likewise omitted from this determination the utilization for oral administration of ferrous gluconate in doses ranging from 0.108 to $0.216 \mathrm{mgm}$. of iron daily is 28.5 per cent.

The problem of toxicity remains to be consid-

2 After these cases were compiled, a patient was studied who had an initial hemoglobin of 5.7 grams or 39 per cent and was given daily doses of ferrous gluconate containing $324 \mathrm{mgm}$. Fe. In 11 days her hemoglobin rose to 11.6 grams or 80 per cent, a daily gain of 0.54 gram or 3.7 per cent. ered. It is difficult to obtain objective evidence of intolerance to iron therapy. The following case, for example, which Dr. William Murphy of Boston kindly permits us to cite, illustrates an experience which is occasionally encountered. The patient had suffered from gastric and intestinal disturbances characterized by nausea, constipation and resulting hemorrhoids following the administration of various forms of iron. She also suffered from rectal irritation associated with nocturia, frequency and burning on urination. After taking 0.3 gram of ferrous gluconate three times a day, these symptoms were all produced but to a less degree than with other forms of iron which she tried. Dr. Murphy writes, "I am sure that she could take short courses with this form of iron with less difficulty than any of 'those which I have previously tried,- - and I think it would be well for her to have these capsules for periodic use if it is possible to obtain them."

While this case is not very striking, a second patient offered a better means of studying the relative toxicity of ferrous gluconate. The patient in question was recovering from a Caesarian delivery and her obstetrician hesitated to give her iron for a slight anemia because she had suffered from gastro-intestinal distress and urticaria when she had received iron previously. At one time an injection of some iron compound had produced intense urticaria. When seen 17 days after her operation she had a red blood cell count of 3,600,000 and a hemoglobin of 11.7 grams or 80 per cent. She was not treated at the time but one and one-half months after discharge from the hospital she was given ferrous gluconate in increasing doses until she received 0.9 gram daily containing $108 \mathrm{mgm}$. of iron with no ill effects. She was then given $35 \mathrm{mgm}$. of iron in the form of ferrous sulphate and within a few hours suffered a violent gastro-intestinal upset. To determine the effect of the intramuscular injection of ferrous gluconate, she was given $0.45 \mathrm{cc}$. of a solution containing $25 \mathrm{mgm}$. of iron per cc. in her left gluteal muscle. For a few hours she had some swelling and soreness but no general reaction and the next morning the local region was practically normal.

At least two patients in this series who suffered no ill effects when taking ferrous gluconate in quantities containing $216 \mathrm{mgm}$. of iron per day, 
complained of indigestion characterized by anorexia, gas and epigastric distress or of constipation when receiving ferrous sulphate in quantities containing from 180 to $249 \mathrm{mgm}$. of iron per day.

\section{DISCUSSION}

To evaluate the efficacy of ferrous gluconate, a comparison with results obtained with various iron compounds by other workers is necessary. However, it must be remembered that the experimental conditions may not be the same in any two studies. For example, Reimann and Fritsch (6) using ferrous chloride in doses which contained $100 \mathrm{mgm}$. of iron a day demonstrated remarkable utilization of the iron, ranging from 17 to 45 per cent. However, all their patients had other forms of iron until a few days before the ferrous chloride was started and some demonstrated excellent reticulocyte responses with these other iron compounds which were supposed to give no appreciable hemoglobin increase. It is obvious that the action of the alleged inactive iron salts cannot be disregarded in the final computations. In fact, these authors concluded that all ferrous compounds have approximately the same effect. It is also contrary to the experience of all other workers that large doses 'of ferric salts are ineffective in hypochromic anemia as Reimann and Fritsch assert. Schulten (7) found that ferrous chloride had to be given in much larger doses and saw no distinct advantage in this iron compound. Davidson (8) reported excellent results with ferrous chloride in doses containing $122 \mathrm{mgm}$. of iron a day but only 2 of his 7 patients attained 80 per cent hemoglobin. Witts (9) gives as the minimum effective daily dose of ferrous carbonate, an amount containing $300 \mathrm{mgm}$. of iron. Probably the best comparison of the efficacy of various iron compounds has been made by Fullerton (10). Table II represents a summary of his results compared with those obtained by oral administration of ferrous gluconate. Only those cases are included in which it seems reasonably certain that there are no factors which either interfere with or accentuate the iron effect. This control necessarily makes the available cases few. It is also important to compare separately the results in patients whose initial hemoglobin values were below and above 50 per cent. In our series, pa-
TABLE II

Relative efficacy of various iron compounds *

\begin{tabular}{|c|c|c|c|c|c|c|}
\hline $\begin{array}{c}\text { Compound } \\
\text { used }\end{array}$ & $\begin{array}{l}\text { Daily iron } \\
\text { dosage }\end{array}$ & $\begin{array}{l}\text { Initial } \\
\text { hemo- } \\
\text { globin }\end{array}$ & $\begin{array}{c}\text { Num- } \\
\text { ber } \\
\text { of } \\
\text { cases }\end{array}$ & $\begin{array}{c}\text { Aver- } \\
\text { age } \\
\text { daily } \\
\text { hemo- } \\
\text { globin } \\
\text { rise }\end{array}$ & $\begin{array}{c}\text { Average } \\
\text { time } \\
\text { before } \\
\text { hemo- } \\
\text { globin } \\
\text { rise }\end{array}$ & $\begin{array}{l}\text { Uti- } \\
\text { liza- } \\
\text { tion } \\
\text { of } \\
\text { iron }\end{array}$ \\
\hline & grams & $\begin{array}{l}\text { per } \\
\text { cent }\end{array}$ & & $\begin{array}{l}\text { per } \\
\text { cent }\end{array}$ & days & $\begin{array}{l}\text { per } \\
\text { cent }\end{array}$ \\
\hline $\begin{array}{l}\text { Ferrous sulfate.... } \\
\text { Ferrous sulfate... }\end{array}$ & $\begin{array}{l}0.180 \\
0.120\end{array}$ & $\begin{array}{l}<50 \\
>50\end{array}$ & $\begin{array}{r}12 \\
3\end{array}$ & $\begin{array}{l}1.175 \\
0.650\end{array}$ & $\begin{array}{l}30 \\
33\end{array}$ & $\begin{array}{l}15.70 \\
13.00\end{array}$ \\
\hline $\begin{array}{l}\text { Iron ammonium } \\
\text { citrate........ }\end{array}$ & 1.215 & $<50$ & 30 & 1.270 & & 2.50 \\
\hline citrate........ & 1.215 & $>50$ & 3 & 1.030 & & 2.03 \\
\hline $\begin{array}{l}\text { Ferrous carbonate } \\
\text { Ferrous carbonate } \\
\text { Ferrous carbonate } \\
\text { Ferrous carbonate } \\
\text { Ferrous carbonate } \\
\text { Ferrous carbonate }\end{array}$ & $\begin{array}{l}0.110 \\
0.110 \\
0.220 \\
0.220 \\
0.330 \\
0.330\end{array}$ & $\begin{array}{l}<50 \\
>50 \\
<50 \\
>50 \\
<50 \\
>50\end{array}$ & $\begin{array}{r}6 \\
3 \\
8 \\
1 \\
10 \\
10\end{array}$ & $\begin{array}{l}0.955 \\
0.520 \\
0.803 \\
0.180 \\
1.125 \\
0.940\end{array}$ & & $\begin{array}{r}20.80 \\
11.30 \\
8.80 \\
1.96 \\
8.18 \\
6.84\end{array}$ \\
\hline $\begin{array}{l}\text { Ferrous chloride. . } \\
\text { Ferrous chloride.. }\end{array}$ & $\begin{array}{l}0.132-0.198 \\
0.132-0.198\end{array}$ & $\begin{array}{l}<50 \\
>50\end{array}$ & $\begin{array}{l}4 \\
3\end{array}$ & $\begin{array}{l}1.420 \\
1.000\end{array}$ & & $\begin{array}{l}20.70 \\
14.50\end{array}$ \\
\hline $\begin{array}{l}\text { Ferrous gluconate } \\
\text { Ferrous gluconate } \\
\text { Ferrous gluconate }\end{array}$ & $\begin{array}{l}0.108 \\
0.108 \\
0.216\end{array}$ & $\begin{array}{l}<50 \\
>50 \\
>50\end{array}$ & $\begin{array}{l}\mathbf{1} \\
\mathbf{5} \\
\mathbf{2}\end{array}$ & $\begin{array}{l}1.550 \\
1.230 \\
1.240\end{array}$ & $\begin{array}{l}38 \\
29 \\
18\end{array}$ & $\begin{array}{l}37.50 \\
29.00 \\
17.25\end{array}$ \\
\hline
\end{tabular}

$* 14.5$ grams $=100$ per cent hemoglobin.

tients whose initiäl hemoglobin readings were below 7.25 grams are rare; in Fullerton's study initial hemoglobin values below 50 per cent were usual. In comparing the effect of the various iron salts it is important to note that all the patients receiving ferrous gluconate orally attained hemoglobin values greater than 11.6 grams or 80 per cent, while in Fullerton's series 9 of the 15 patients treated with ferrous sulphate and 2 of the 3 taking ferrous carbonate for whom data is given failed to reach such a level.

Since Barkan's (11) and Meulengracht's (12) reports, most clinicians feel that large doses of iron are essential in treating hypochromic anemia $(13,14,15,3,16)$. Whipple and RobscheitRobbins (17), working with standard anemic dogs, emphasize the fact that the particular type of iron is unimportant as long as it is given in large doses. However, Fürth and Scholl (18) found that ferrous salts are much more easily absorbed from intestinal loops of rabbits than ferric compounds and most workers who advocate large doses of iron admit that ferrous salts are more efficiently utilized in patients $(14,3)$. Bethell, Goldhamer, Isaacs and Sturgis (19) feel the same about soluble iron salts. The results of most studies show, however, that large doses of iron may not produce a normal blood count for a considerable time (15) and occasionally rather small 
doses of iron will cause surprising improvement (20).

The real problem of iron therapy is not the theoretical utilization of iron, or the reticulocyte response, or even the daily increase of hemoglobin for any particular period of treatment. These are important only as they indicate the return of the patients' blood to normal in a reasonably short time without undue inconvenience. Most patients suffering from hypochromic anemia respond well to most forms of iron when administered in adequate dosage. For the patients who cannot tolerate the usual iron compounds, it is important to have a medication which is effective and which causes minimum disturbance. For all patients in need of iron it is desirable to use a compound which gives good results with the least discomfort. Ferrous gluconate seems to be such a medicament.

\section{CONCLUSIONS}

1. Ferrous gluconate prepared in the absence of oxygen has been used in the treatment of 13 patients suffering from hypochromic anemia.

2. The use of ferrous gluconate compared with other iron preparations results in satisfactory reticulocyte responses, a high percentage utilization of iron, and such daily increase in hemoglobin that a normal level occurs in a reasonably short time.

3. Four patients, who showed toxic reactions to other iron compounds, were able to take ferrous gluconate without any undue distress.

4. In the patients who received ferrous gluconate intramuscularly up to the present no systemic and only rare and mild local reactions occurred. However, in view of the efficacy of the oral administration of ferrous gluconate and its lack of toxicity there is seldom any reason for its parenteral administration.

\section{BIBLIOGRAPHY}

1. Reznikoff, P., and Goebel, W. F., The preparation of ferrous gluconate and its use in the treatment of hypochromic anemia in rats. J. Pharmacol. and Exper. Therap., 1937, 59, 182.

2. Neiger, R., and Neuschul, P., Uber photochemische Reaktionen der Eisengluconate. Ztschr. f. physikal. Chem., 1936, 177, Alt A., 355.
3. Heath, C. W., Oral administration of iron in hypochromic anemia. Arch. Int. Med., 1933, 51, 459.

4. Heath, C. W., Strauss, M. B., and Castle, W. B., Quantitative aspects of iron deficiency in hypochromic anemia (The parenteral administration of iron). J. Clin. Invest., 1932, 11, 1293.

5. Whipple, G. H., and Robscheit-Robbins, F. S., Blood regeneration in severe anemia. XVI. Optimum iron therapy and salt effect. Am. J. Physiol., 1930, 92, 362.

6. Reimann, F., and Fritsch, F., Vergleichende Untersuchungen zur therapeutischen Wirksamkeit der Eisenverbindungen bei den sekundären Anämien. Ztschr. f. klin. Med., 1930, 115, 13.

7. Schulten, H., Zur Klinik der essentiellen hypochromen Anämie. Munch. med. Wchnschr., 1935, 82, 697.

8. Davidson, L. S. P., Discussion on the treatment of the anemias before Section of Therapeutics and Section of Medicine. Proc. Roy. Soc. Med., 1933, 26, 616.

9. Witts, L. J., Discussion on the treatment of the anaemias. Proc. Roy. Soc. Med., 1933, 26, 607.

10. Fullerton, H. W., The treatment of hypochromic anaemia with soluble ferrous salts. Edinburgh $\mathrm{M}$. J., 1934, 41, 99.

11. Barkan, G., Therapie der Anämien mit grossen Eisengaben. Klin. Wchnschr., 1923, 2, 1748.

12. Meulengracht, E., Large doses of iron in the different kinds of anemia in a medical department. Acta med. Scandinav., 1923, 58, 594.

13. Keefer, C. S., Huang, K. K., and Yang, C. S., Liver extract, liver ash and iron in the treatment of anemia. J. Clin. Invest., 1931, 9, 533.

14. Minot, G. R., Idiopathic hypochromic anemia. Emanuel Libman Anniversary Volume, International Press, New York, 1932, 2, 831.

15. Wintrobe, M. M., and Beebe, R. T., Idiopathic hypochromic anemia. Medicine, 1933, 12, 187.

16. Bethell, F. H., The application of diagnostic criteria to the treatment of the anemias. New York State J. Med., 1935, 35, 799.

17. Whipple, G. H., and Robscheit-Robbins, F. S., I. Iron and its utilization in experimental anemia. Am. J. M. Sc., 1936, 191, 11.

18. Fürth, O., and Scholl, R., The absorption of ferrous and ferric compounds from the intestines of rabbits. J. Pharmacol. and Exper. Therap., 1936, 58, 14.

19. Bethell, F. H., Goldhamer, S. M., Isaacs, R., and Sturgis, C. C., The diagnosis and treatment of the iron-deficiency anemias. J. A. M. A., 1934, 103, 797.

20. Vaughan, J. M., The haematopoietic response to therapy in non-tropical anaemias. Tr. Roy. Soc. Trop. Med. and Hyg., 1934, 27, 533. 